\title{
PERANCANGAN ILUSTRASI TATA CARA PENGGUNAAN KENDARAAN UMUM SEBAGAI MEDIA EDUKASI
}

\author{
Edo Galasro Limbong ${ }^{1}$; Ismail Bambang Subianto²; Friza Youlinda Parwis ${ }^{3}$; Prin Suprianto ${ }^{4}$ \\ Desain Komunikasi Visual, Universitas Indraprasta PGRI Jakarta ${ }^{1,2,4}$ \\ Pendidikan Bahasa Indonesia, Universitas Indraprasta PGRI Jakarta ${ }^{3}$ \\ Email: edogalasrolimbong@yahoo.com¹; subianto.ismail@gmail.com²; frizayou297@gmail.com³; \\ prinsuprianto20@gmail.com ${ }^{4}$
}

\begin{abstract}
Abstrak
Tata cara merupakan suatu proses yang sering diabaikan oleh seseorang karena dianggap tidak terlalu penting, tidak ada aturan yang ketat, tidak ada edukasi yang jelas, dan sebagainya. Tata cara sendiri berkaitan erat dengan tata krama karena perihal tindakan atau perbuatan. Pada dasarnya melakukan tata cara dapat berdampak kepada orang-orang di sekitarnya. Salah satunya adalah tata cara penggunaan kendaraan umum mobil angkot dan kereta MRT. Edukasi terhadap tata cara penggunaan perlu untuk dilakukan dimulai dari usia remaja. Sehingga tujuan dari penelitian ini adalah untuk merancang media ilustrasi tata cara penggunaan kendaraan umum sebagai media edukasi. Penelitian ini menggunakan metode penelitian kualitatif dengan pendekatan yang dilakukan adalah proses kreatif penciptaan karya. Teknik pengumpulan data penelitian ini adalah dengan observasi di lapangan, wawancara, dan studi pustaka. Dengan demikian, hasil penelitian ini adalah ilustrasi-ilustrasi tata cara penggunaan kendaraan umum mobil angkot dan kereta MRT yang bisa digunakan sebagai media informasi dan edukasi bagi usia remaja.
\end{abstract}

Kata Kunci: Ilustrasi, Tata Cara, Kendaraan Umum, Angkot, MRT

\section{Abstract}

Procedure is a process that is often overlooked by someone because it is considered not too important, there are no strict rules, no clear education, and so on. The procedure itself is closely related to manners because of matters regarding actions or actions. Basically doing procedures can have an impact on the people around them. One of them is the procedure for using public vehicles for angkot cars and MRT trains. Education on the procedures for use needs to be done starting from adolescence. So the purpose of this study is to design an illustrative media for how to use public vehicles as an educational medium. This research uses qualitative research methods with the approach taken is the creative process of creating works. The data collection technique of this research is by field observations, interviews, and literature studies. Thus, the results of this study are illustrations of procedures for public vehicle use of angkot cars and MRT trains that can be used as a medium of information and education for teenagers.

Keywords: Illustrations, Procedure, Public Transportation. Angkot, MRT

\section{PENDAHULUAN}

Tata cara merupakan salah satu hal yang berkaitan dengan tata krama, karena berhubungan dengan perilaku atau tindakan seseorang. Tata cara yang sudah mulai kurang dilakukan salah satunya adalah tata cara penggunaan kendaraan umum. Hal ini mengingat bahwa manusia merupakan makhluk mobilisasi yang di dalam kehidupan sehari-harinya membutuhkan alat transportasi atau biasa disebut juga dengan kendaraan. Salah satu jenis kendaraan yang dapat digunakan adalah kendaraan umum, seperti becak, angkot, bus, kereta rel listrik, atau pun taksi. Jumlah masyarakat Indonesia yang menggunakan kendaraan umum masih beda tipis dengan masyarakat yang menggunakan kendaraan pribadi. Berdasarkan hasil survei yang berhubungan dengan transportasi harian jumlah pengguna kendaraan umum orang Indonesia sebesar 52,4\% [1]. Kendaraan umum pada banyak negara semakin berkembang bukan hanya dikarenakan pengembangan teknologi yang digunakan, 
akan tetapi teraturnya pergerakan masyarakat serta memiliki dan memperhatikan perilaku atau tata cara dalam menunggu hingga menggunakan kendaraan umum tersebut. Misalnya, mengantri dengan tertib saat masuk ke dalam kendaraan, mengutamakan penumpang yang turun, dan sebagainya. Berbagai tata cara tersebut ada yang diumumkan dan ada pula yang ditempelkan pada kaca kendaraan berbentuk stiker untuk dapat dilihat dan dipatuhi bersama.

Berbagai pelanggaran tata cara dalam menggunakan kendaraan umum kerap terjadi seperti di daerah Karawang di mana pelajar sekolah menengah pertama (SMP) yang gelantungan di angkot sudah menjadi tradisi walaupun hal tersebut dangat berbahaya bahkan dapat mengancam jiwa [2]. Hal tersebut dapat dicegah apabila setiap pengguna kendaraan umum mau melakukan tata cara penggunaan kendaraan umum. Termasuk dalam penggunaan kendaraan umum mobil angkot atau yang lebih dikenal dengan angkot dan kereta MRT atau yang lebih dikenal dengan MRT. Namun, tidak sedikit pelanggaran tata cara penggunaan kendaraan umum yang terjadi, antara lain masih ada orang yang gelantungan di sisi angkot pada saat tidak mendapatkan kursi untuk duduk di dalam angkot, saling dorong untuk masuk ke dalam angkot dan MRT hingga ada yang terjatuh, dan masih banyak lainnya.

Walaupun pada beberapa kendaraan umum seperti kereta MRT, telah ada tempelan stiker berisikan himbauan yang berkaitan dengan tata cara dalam menggunakan kendaraan umum baik di dalam stasiun hingga di dalam kereta itu sendiri. Akan tetapi hal tersebut masih dirasa kurang. Masih perlu dilakukan pendekatan yang mendalam terutama bagi para remaja untuk menyampaikan bahwa dalam menggunakan kendaraan umum memiliki tata caranya. Sehingga dibutuhkan sebuah gambar-gambar ilustrasi sebagai media edukasi. Dengan demikian, dalam melakukan pendekatan tidak dengan cara kekerasan, akan tetapi dengan psikologis melalui bantuan gambar-gambar ilustrasi tersebut.

Ilustrasi berasal dari kata latin illustrate, yang memiliki arti menerangi atau memurnikan. Sehingga Ilustrasi merupakan sebuah citra yang dibentuk untuk memperjelas sebuah informasi dengan memberi representasi secara visual. Sehingga esensi dari ilustrasi adalah pemikiran; ide dan konsep yang melandasi apa yang ingin dikomunikasikan gambar [3]. Penggunaan gambar-gambar ilustrasi digunakan karena memiliki beberapa fungsi, salah satunya fungsi ilustrasi yang paling menonjol dalam rancangan gambargambar ilustrasinya adalah fungsi ekspresif, karena menunjukkan dan menyatakan suatu gagasan, perasaan, maksud, situasi ataupun konsep yang abstrak secara nyata sehingga lebih mudah dipahami [4]. Dalam rancangan gambar ilustrasi, dalam perancangan media ilustrasi tata cara penggunaan kendaraan umum angkot dan MRT ini mengandung suatu pesan yang berisikan fungsi informasi, yakni fungsi yang mengirimkan pengetahuan yang mungkin merubah atau tidak merubah khalayak, dan kontrol, yakni mempengaruhi tingkah laku dan pemikiran orang sesuai dengan cara yang kita ingin, untuk disampaikan kepada target khalayak yang dituju [5].

Masih banyaknya jumlah masyarakat terutama yang usia remaja belum memahami tata cara dalam menggunakan kendaraan umum. Selain itu belum banyaknya media untuk digunakan sebagai media dalam memberikan himbauan atau pun edukasi tentang tata cara menggunakan kendaraan umum, yakni 
angkot yang sudah lama ada dan masih terus digunakan serta MRT (Mass Rapid Transportation) berupa kereta cepat yang pada tahun 2019 diresmikan. Oleh sebab itu, hal inilah yang membuat tim peneliti tertarik untuk perlu melakukan penelitian ini. Sehingga semakin banyak pihak terutama para remaja yang dapat menunjukkan tata cara yang baik dalam menggunakan, menaiki kendaraan umum.

\section{METODE}

Metode dalam penelitian ini adalah kualitatif. Pendekatan yang dilakukan adalah perancangan karya [6]. Teknik pengumpulan data dengan observasi, wawancara, dan studi pustaka [7]. Serta teknik analisis datanya adalah reduksi data, penyajian, dan kesimpulan [8].

\section{HASIL DAN PEMBAHASAN \\ Angkot dan permasalahan tata cara penggunaannya}

Berdasarkan data dari okezone.com menyatakan bahwa keberadaan angkot di negara Indonesia dapat dikatakan sudah ada sejak zaman pendudukan Jepang di Indonesia pada tahun 1943. Pada saat itu, pemerintah militeri Jepang membentuk dua institusi angkutan berbayar, yakni Jawa Unyu Zigyosha yang berupa kendaraan truk, gerobak atau cikar (sejenis dokar) serta Zidosha Sokyoku, kendaraan dengan mesin bermotor dan bus. Setelah Indonesia merdeka, Jawa Unyu Zigyosha diubah namanya jadi Djawatan Pengangkoetan untuk angkutan barang, serta Zidosha Sokyoku menjadi Djawatan Angkutan Darat untuk penumpang. Kemudian kedua jawatan tersebut digabungkan pada 25 November 2946 menjadi Damri [9].

Lalu, armada Damri lebih banyak digunakan oleh masyarakat sebagai transportasi antarkota. Oleh sebab itu, angkutan umum khusus untuk mengangkut masyarakat melakukan aktivitas di dalam kota menjadi sangat minim. Kemunculan angkot pada setiap kota berbeda-beda, salah satu contohnya di kota Bandung. Berdasarkan data dari liputan6.com menyatakan bahwa angkot muncul di kota Bandung dikarenakan adanya suatu inisiatif dari dealer mobil [10]. Dealer mobil tertentu melihat suatu potensi untuk dijadikan jalur angkot, kemudian mereka melakukan sebuah kajian supaya dapat diizinkan untuk membuka jalur angkot tersebut. Hal tersebut berlangsung dari tahun 1992 sampai 2000.

Perkembangan jumlah angkot pun setiap tahunnya terus bertambah. Ada angkot yang memang terdaftar secara resmi dan ada pula yang tidak. Semakin berkembangnya jumlah angkot yang beredar di masyarakat sampai terdapat salah satu kota di Indonesia yang dijuluki sebagai kota seribu angkot, yakni kota Bogor. Hal tersebut karena sampai tahun 2014 terdapat sekitar 3.412 unit [11]. Jumlah mobil angkot yang terus berkembang seiring dengan jumlah populasi masyarakat yang terus berkembang. Selain itu, masih ada masyarakat yang mengandalkan angkot sebagai salah satu trasnportasi untuk sampai di tujuannya masing-masing. Dalam berjalannya waktu kendala demi kendala terjadi, salah satunya adalah tata cara masyarakat dalam menggunakan mobil angkot ini semakin tidak bisa diatur yang membuat situasi tidak nyaman, menimbulkan rasa takut, dan lain sebagainya. Salah satu penyebabnya adalah tidak adanya tata cara yang baku dalam menggunakan angkot untuk dipatuhi oleh masyarakat.

Berdasarkan hasil observasi lapangan dan bertanya kepada masyarakat yang telah dilakukan oleh tim peneliti, permasalahanpermasalahan yang berkaitan dengan tata cara penggunaan angkot antara lain masih banyak masyarakat yang turun dan naik di sembarang tempat sehingga menimbulkan 
kemacetan, pada halte tempat menunggu masih banyak bekas corat-coret serta sampah yang tergeletak di lantai, saat naik ke dalam angkot masih ada yang kurang tertib salah satunya saling dorong, terutama dilakukan oleh pelajar yang menaiki angkot bersama-sama dengan temannya, di beberapa daerah masih didapati adanya penumpang yang berdiri pada sisi samping angkot di saat tidak mendapatkan kursi untuk duduk di dalam mobil angkot, dan lain sebagainya.

\section{MRT dan permasalahan tata cara penggunaannya}

MRT merupakan salah satu transportasi umum yang berbentuk kereta yang berada di kota Jakarta dan diresmikan oleh Presiden Joko Widodo pada hari Minggu, 24 Maret 2019. MRT dikelola oleh PT Mass Rapid Transporatation (PT MRT Jakarta) yang berdiri sejak tanggal 17 Juni 2008, yang mayoritas sahamnya dimiliki oleh Pemerintah Provinsi DKI Jakarta (struktur kepemilikan: Pemprov DKI Jakarta 99,98\%, PD Pasar Jaya 0,02\%). Rencana pembangunan MRT di Jakarta telah dirintis sejak tahun 1985. Setelah berjalannya waktu proyek MRT Jakarta dimulai dengan pembangunan jalur MRT fase 1 sepanjang kurang lebih $16 \mathrm{~km}$ dari Terminal Lebak Bulus menuju Bundaran Hotel Indonesia yang memiliki 13 stasiun [12].

MRT telah banyak digunakan di kota-kota metropolitan yang penduduknya padat. Ciri-ciri dari MRT antara lain dapat mengangkut penumpang dalam jumlah besar dengan jarak transit pendek, dan memiliki waktu tunggu di setiap stasiun yang pendek pula. MRT di kota besar umumnya bermobilisasi di bawah tanah, rel laying atau permukaan tanah [13]. MRT (Mass Rapid Transit) merupakan salah satu bukti perkembangan transportasi umum yang ada di Indonesia khususnya untuk wilayah Provinsi DKI Jakarta. Telah beroperasinya kendaraan umum MRT ini tujuannya untuk dapat mengurangi kemacetan di wilayah kota Jakarta terutama pada pusat-pusat aktivitas perkantoran kota Jakarta, seperti Blok M, Senayan hingga Bunderan Hotel Indonesia. Walaupun transportasi umum MRT baru diresmikan pada bulan April 2019, masih tampak permasalahan yang berkaitan dengan tata cara penggunaan MRT tersebut.

Pada tanggal 1 April 2019 mulai berlaku dikenakannya tarif bagi pengguna MRT. Berdasarkan lampiran Surat Gubernur Provinsi Daerah Khusus Ibu Kota Jakarta Nomor 178/-1.118.3 tertanggal 25 Februari 2019, tarif termurah MRT sebesar Rp 3.000 dan tarif termahalnya adalah $\mathrm{Rp}$ 14.000 [14]. Walaupun dikenakan tarif, jumlah penumpang yang menggunakan transportasi umum MRT sampai pada tanggal 17 Mei 2019 sebanyak 89.372 orang [15].

Setelah melakukan observasi langsung ke beberapa stasiun dan masuk ke dalam MRT, tim peneliti mendapatkan beberapa permasalahan yang berkaitan dengan tata cara penggunaan MRT, yaitu: masih terdapat orang tua yang membiarkan anakanaknya untuk naik-naik bahkan lompatlompat di atas kursi MRT, masih ada calon penumpang yang ingin langsung masuk ke dalam MRT saat pintunya telah terbuka, beberapa masyarakat ada yang bingung untuk menempelkan kartu saat masuk dan keluar dari stasiun, didapati beberapa orang yang masih minum di dalam kereta, dan Masih ada orang-orang yang tidak memberikan kursi prioritas bagi orangorang yang layak untuk duduk di kursi prioritas tersebut.

\section{Perancangan}

Tim peneliti melakukan sortir terhadap permasalahan-permasalahan yang berkaitan dengan tata cara penggunaan 
kendaraan umum angkot dan MRT berdasarkan hasil observasi yang telah dilakukan. Permasalahan yang berkaitan dengan tata cara penggunaan kendaraan umum angkot dan MRT dibagi dalam tiga hal, yaitu:

a. Sebelum naik ke dalam kendaraan

b. Saat berada dalam kendaraan

c. Keluar dari kendaraan

Kemudian tim peneliti menyusun kata-kata dan gambar ilustrasi tata cara penggunaan kendaraan umum angkot ataupun MRT. Berikut adalah hasil yang disortir secara mendalam tentang tata cara penggunaan kendaraan umum angkot dan MRT:

a. Angkot

Tabel 1. Ilustrasi dan Keterangan Tata

Cara Penggunaan Kendaraan Umum

Angkot

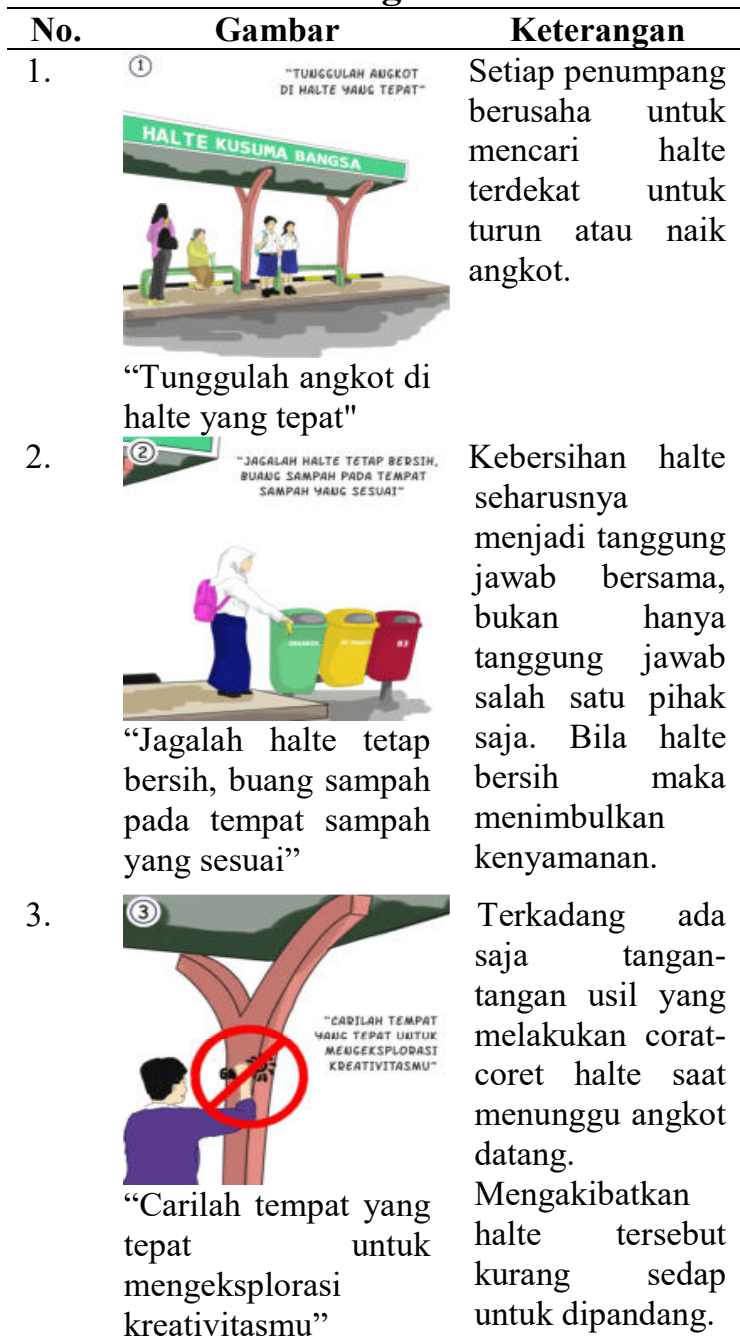

4.

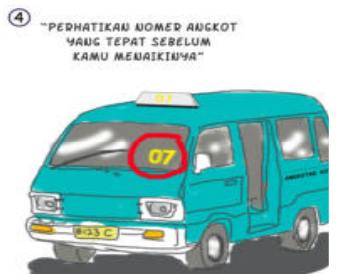

Perhatikan nomor angkot wajib dilakukan, sehingga bisa ditujuan tanpa harus salah arah

"Perhatikan nomor angkot yang tepat sebelum kamu menaikinya"

5.

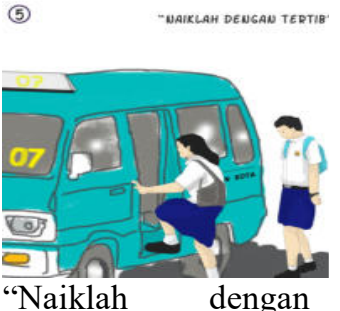
tertib"

6.
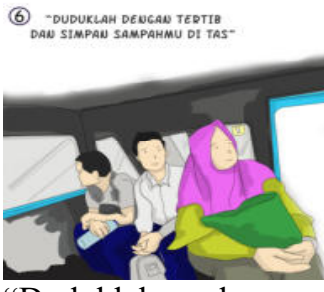

"Duduklah dengan tertib dan simpan sampahmu di tas"

7. (7) -UCAPRAU PEDMISI SAAT

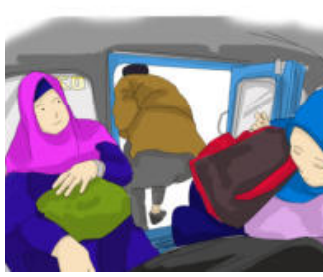

"Ucapkan permisi saat kamu hendak turun"

8. (8) "LEBH BAIK DUDUK DD DALAM AUGKOT ATAU TUUGGULAH

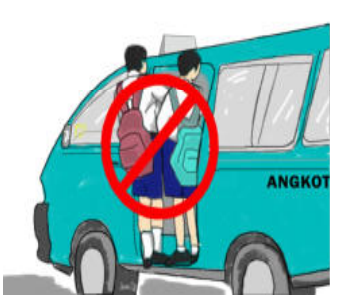

"Lebih baik duduk di dalam angkot atau tunggulah angkot berikutnya"
Saling dorong naik angkot bukanlah hal yang baik untuk dilakukan. Bisa melukai penumpang lain, kepala terbentur, dan sebagainya.

Saat berada di dalam angkot duduklah dengan posisi saling berhadapan

bukan posisi serong sehingga membuat penumpang lain merasa

kesempitan.

Mengucapkan permisi saat akan turun perlu dilakukan untuk memberikan kode kepada penumpang lain ada yang akan turun dari angkot.

Bila angkot penuh lebih baik menunggu angkot yang berikutnya bukan gelantungan di sisi luar angkot. Harus menolak bila disuruh oleh supir angkotnya, demi keselamatan penumpangnya. 
9.
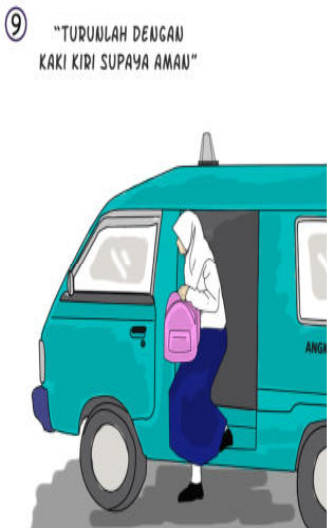

"Turunlah dengan kaki kiri supaya aman"

10.

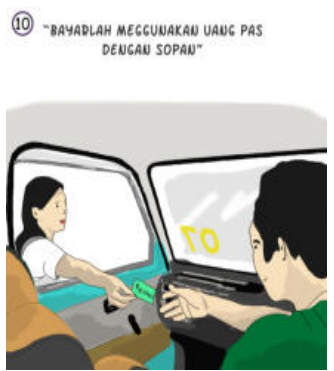

"Bayarlah

menggunakan uang pas dengan sopan"
Kebanyakan

posisi pintu angkot berada di sebelah kiri, sehingga

membuat para penumpang harus menurunkan kaki kiri sebagai tumpuan di jalan. Walaupun belum ada alasan pasti yang dapat menjelaskannya. Selain itu, saat akan turun harus perlahan-lahan.

Berikanlah uang pas saat membayar tarif, untuk mempermudah pengemudinya, dapat menghemat waktu dan tidak menimbulkan kemacetan. Serta tidak dengan melempar uangnya.

\section{b. MRT}

Tabel 2. Ilustrasi dan Keterangan Tata Cara Penggunaan Kendaraan Umum MRT

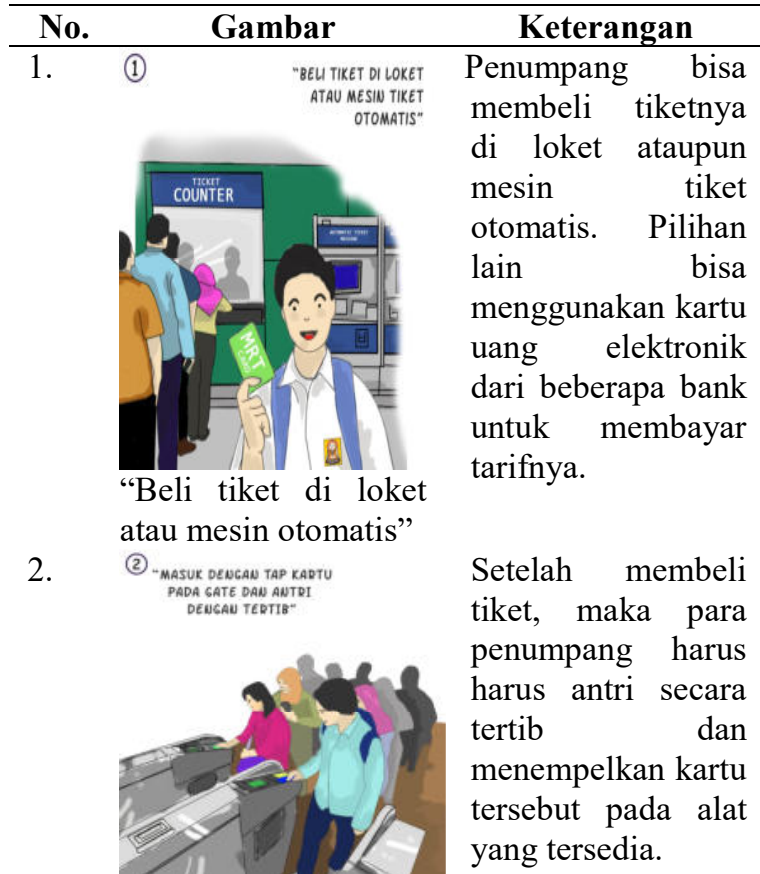

"Masuk dengan tap kartu pada gate dan antri dengan tertib"

3.

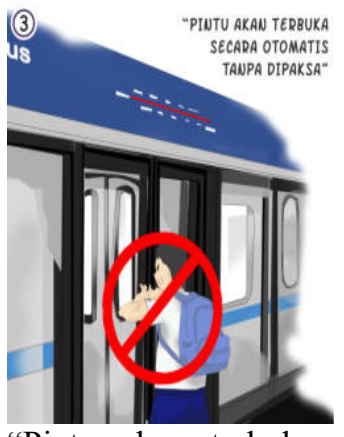

Pada saat kereta MRT telah tiba kita tetap harus sabar menunggu dan jangan membuka paksa terutama pada pintu lapis pertama sebelum masuk ke dalam

"Pintu akan terbuka secara otomatis tanpa dipaksa"

4.
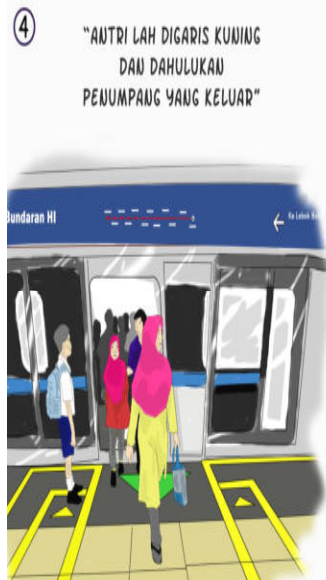

"Antri lah di garis kuning dan dahulukan penumpang yang keluar"

5. (5) "MAKan DAN MTUUM DI DALAM KERETA
aKAU MENGOTORI GERBONG"

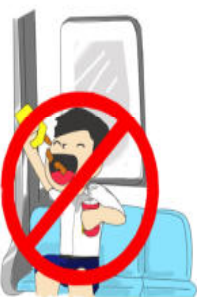

"Makan dan minum di dalam kereta akan mengotori gerbong"

6. (6) -xuss uetrux opoupure

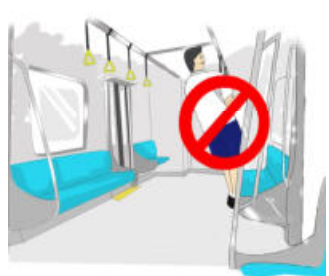

Penumpang harus menunggu di jalur berwarna kuning yang berarti area untuk menunggu yang diposisikan pada sebelah kanan dan kiri pintu. Sedangkan untuk jalur tengah dikhususkan jalur bagi para penumpang yang akan turun dari kereta.

Hal ini bertujuan kebersihan kereta supaya tidak ada aroma yang tidak sedap dari bekas makanan atau pun minuman dari penumpang.

Selama perjalanan menggunakan

kereta MRT satu kursi untuk satu penumpang. Serta tidak berdiri di atas kursi terutama bagi orang tua yang supaya menjaga 
"Kursi diduduki"

untuk

7.
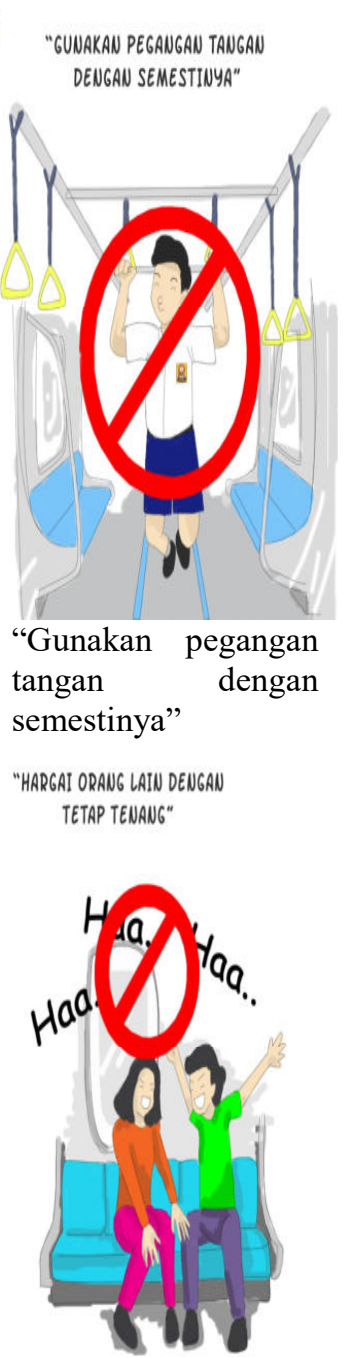

"Hargai orang lain dengan tetap tenang"

9.

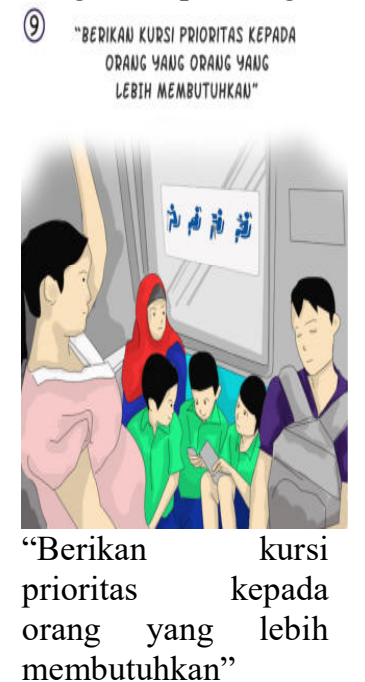

Berikanlah kursi prioritas kepada orang-orang yang membutuhkan, seperti penumpang yang berusia lanjut, ibu hamil, dan sebagainya. Mereka lebih layak untuk menempatinya. anak. Sehingga

kursi dalam kereta

Pegangan tangan

pada kereta

digunakan sebagai

pegangan bagi

penumpang yang

berdiri supaya tidak

jatuh. Pegangan

digunakan untuk

bermain

gelantungan.

Dampaknya akan merusak pegangan tersebut.

Di dalam MRT terdapat

penumpang lainnya.

Oleh sebab itu,

setiap penumpang

wajib untuk

menjaga

ketenangan selama

di dalam kereta

supaya tidak

mengganggu

penumpang lain. membawa anak-
10.

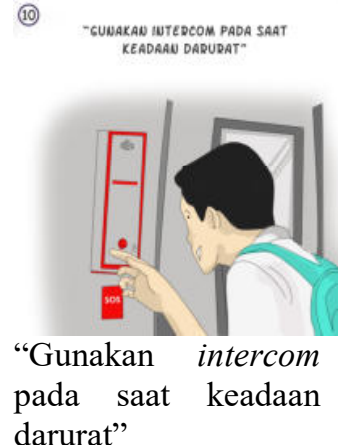

11.

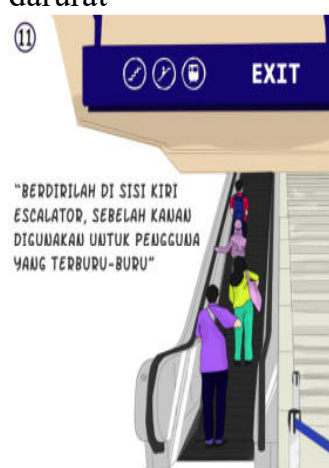

"Berdirilah di sisi kiri escalator, sebelah kanan digunakan untuk pengguna yang terburu-buru"

12.

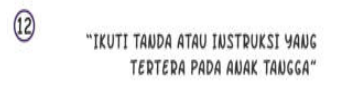

Penggunaan tangga tidak jauh berbeda dengan penggunaan escalator pada setiap stasiun.

Setiap stasiun.
harus berbagi jalur
antara penumpang
yang akan turun
dengan penumpang
yang akan naik.

\section{SIMPULAN}

Tata cara merupakan hal yang terdengar mudah, tapi sulit untuk dilakukan. Sehingga melalui edukasi, tata cara dapat dilakukan dalam kehidupan sehari-hari, termasuk tata cara penggunaan kendaraan umum angkot dan MRT perlu dilakukan yang dimulai dari usia remaja melalui gambar-gambar ilustrasi yang bentuknya semirealis (hampir menyerupai bentuk aslinya). Seluruh perancangan gambar- 
gambar ilustrasi tentang tata cara penggunaan kendaraan umum angkot dan MRT dapat dijadikan sebagai pengingat dan salah satu sumber edukasi mulai dari usia remaja. Dalam kreatif perancangan ilustrasi yang telah dibuat memperhatikan berbagai hal pada unsur penggunaan warna, kata-kata, karakter, tipografi yang mendekati target khalayak yang dituju.

\section{DAFTAR PUSTAKA}

[1] Fitriya. "Hasil Survei Ternyata Transportasi Umum Ini yang Digandrungi Orang Indonesia," Cermati.com, 2018, [Online]. Available:

https://www.cermati.com/artikel/hasi 1-survei-ternyata-transportasi-umumini-yang-digandrungi-orangindonesia. [Accessed: 24-Jan-2019].

[2] A. Satria. "Gelantungan di Angkot Jadi Tradisi," radar-karawang.com, 2016.

[3] J. Witabora. "Peran dan Perkembangan Ilustrasi”. Humaniora, vol. 3, no. 2, pp. 659667, 2012.

[4] S. Arifin dan A. Kusrianto. Sukses Menulis Buku Ajar \& Referensi. Jakarta: PT Gramedia Widiasarana Indonesia, 2009.

[5] I. Hamad. Perancangan Program Komunikasi. Kedua. Jakarta: Universitas Terbuka, 2007.

[6] A. Amri. Metode Penelitian Desain Komunikasi Visual. Bekasi: CAKRA PRESS, 2016.

[7] A. Anggito dan J. Setiawan. METODOLOGI PENELITIAN KUALITATIF. Sukabumi: CV Jejak, 2018.

[8] L. J. Moleong. Metode Penelitian Kualitatif. Revisi. Bandung: PT. Remaja Rosda Karya, 2016.

[9] Randy Wirayudha. "Mengenal 'Angkot' Pertama di Indonesia," 2015, [Online]. Available: https://news.okezone.com/read/2015/ 04/24/337/1139419/mengenalangkot-pertama-di-indonesia. [Accessed: 13-Jun-2019].

[10] "Sejarah Warna-warni Angkot Jadul di Bandung," 2019, [Online]. Available:

https://www.liputan6.com/regional/r ead/3928745/sejarah-warna-warniangkot-jadul-di-bandung. [Accessed: 13-Jun-2019].

[11] R. Frizky. "Angkot Fest, Solusi Kreatif Pemerintah Atasi Permasalahan Sosial Angkutan Umum di Bogor", [Online]. Available:

http://suarajakarta.co/ekstra/jurnaliswarga/angkot-fest-solusi-kreatifpemerintah-atasi-permasalahansosial-angkutan-umum-di-bogor/. [Accessed: 13-Jun-2019].

[12] "Sejarah", [Online]. Available: https://www.jakartamrt.co.id/mrtjakarta/sejarah-mrt-jakarta/. [Accessed: 14-Jun-2019].

[13] A. S. Dayana. "Perbedaan MRT, LRT dan KRL Commuter Line", 2019, [Online]. Available: https://tirto.id/perbedaan-mrt-lrt-dankrl-commuter-line-eciA. [Accessed: 14-Jun-2019].

[14] W. Marison. "Berlaku 1 April, Ini Tarif MRT dari Setiap Stasiun...", 2019, [Online]. Available: https://megapolitan.kompas.com/rea d/2019/04/01/06550431/berlaku-1april-ini-tarif-mrt-dari-setiapstasiun?page $=$ all. [Accessed: 14-Jun2019].

[15] R. A. Umasugi. "Meski Diskon Berakhir, Jumlah Pengguna MRT Kembali Naik 10 Persen pada Jumat", 2019, [Online]. Available: https://megapolitan.kompas.com/rea d/2019/05/18/12505651/meskidiskon-berakhir-jumlah-penggunamrt-kembali-naik-10-persen-pada. [Accessed: 14-Jun-2019]. 